\title{
Effect of fragmentation on the natural genetic diversity of Theobroma speciosum Willd. ex Spreng. populations
}

\author{
T.L. Varella ${ }^{1}$, A.A.B. Rossi ${ }^{2}$, J.F.E. Dardengo ${ }^{2}$, G.F. Silveira ${ }^{1}$, \\ M.D.A. Souza ${ }^{1}$ and M.L.S. Carvalho ${ }^{3}$ \\ ${ }^{1}$ Laboratório de Genética Vegetal e Biologia Molecular, \\ Universidade do Estado de Mato Grosso, campus de Alta Floresta, MT, Brasil \\ ${ }^{2}$ Laboratório de Genética Vegetal e Biologia Molecular, \\ Rede Bionorte/MT, Faculdade de Ciências Biológicas e Agrárias, \\ Universidade do Estado de Mato Grosso, campus de Alta Floresta, MT, Brasil \\ ${ }^{3}$ Laboratório de Genética/Cultura de Tecido Vegetal, CPEDA, \\ Faculdade de Ciências Biológicas e Agrárias, \\ Universidade do Estado de Mato Grosso, campus de Tangará da Serra, MT, Brasil \\ Corresponding author: A.A.B. Rossi \\ E-mail: anabanrossi@unemat.com
}

Genet. Mol. Res. 15 (4): gmr15048630

Received March 21, 2016

Accepted September 16, 2016

Published November 21, 2016

DOI http://dx.doi.org/10.4238/gmr15048630

Copyright $(2016$ The Authors. This is an open-access article distributed under the terms of the Creative Commons Attribution ShareAlike (CC BY-SA) 4.0 License.

\begin{abstract}
Forest fragmentation reduces the effective size of natural populations, isolates individuals in the landscape, and, consequently, changes species' mating systems by increasing the degree of relatedness between individuals and inbreeding. Investigating the impact of habitat degradation on forest fragments helps to assess the genetic and ecological consequences of these changes, and allows the development of effective and sustainable conservation strategies to manage the genetic resources of species living in degraded landscapes. The aim
\end{abstract}


of the present study was to assess the genetic diversity of fragmented Theobroma speciosum populations using microsatellite markers. Three urban forest fragments were selected in the municipality of Alta Floresta, Mato Grosso State, Brazil, namely C/E park, J park, and Zoo Botanical park. Seventy-five individuals (25 in each fragment) were sampled by collecting their leaves for genomic DNA extraction. Polymerase chain reaction amplifications were performed using nine polymorphic simple sequence repeat primers, which amplified 84 alleles. The mean expected heterozygosity was 0.970 , and it was always higher than the observed heterozygosity. Analysis of molecular variance revealed that most variability occurred within populations $(64 \%)$ rather than between them (36\%). The Structure software and an unweighted pair group method with arithmetic mean dendrogram revealed three distinct groups, showing that individuals were allocated to their correct populations. Genotype number 3 from C/E park, number 45 from J park, and number 51 from Zoo Botanical park could be used as stock plants in breeding programs, because they were the most dissimilar within the populations studied. The high genetic diversity levels detected in all three populations studied emphasize the importance of protecting this species in its natural habitat.

Key words: Genetic variability; SSR marker; Amazon

\section{INTRODUCTION}

Brazil contains a wide variety of soil and climate types, which favors the cultivation of many tropical fruit trees (Simão, 1998). The most diverse botanical families in the Amazon are the Fabaceae, Bignoniaceae, Lauraceae, Lecythidaceae, Rubiaceae, Anacardiaceae, Malvaceae, Asteraceae, Araceae, Arecaceae, and Poaceae, among others (Neto and Silva, 2011). The Theobroma genus (Malvaceae) comprises 22 species that are found in the Americas (Cuatrecasas, 1964). Eight of these species, including the trees cacau (Theobroma cacao L.), cupuassu [Theobroma grandiflorum (Willd.) Schum.], cacauhy (Theobroma speciosum Willd. ex Spreng.), and cupuí (Theobroma subincanum Mart.), are found in the Brazilian Amazon. According to Souza and Venturieri (2009), T. speciosum is important because it represents a possible source of genetic resistance for other more economically important species, such as T. cacao and T. grandiflorum. T. speciosum is found in the Amazon basin, and is widely distributed in Mato Grosso State. It has an edible fruit, and its flesh can be consumed fresh or as a juice (Neto and Silva, 2011). Its seeds are commonly used to prepare homemade chocolate (Ferrão, 2001).

Wild species, such as T. speciosum, provide a source of income for native communities. These species are very profitable for regional development, promote the rational use of native genetic resources, and encourage native communities in the conservation of plants' genetic resources.

However, native Theobroma species have been subjected to strong anthropogenic genetic erosion (Alves et al., 2013), which has isolated populations into small fragments, decreased the number of individuals and the population density, and affected genetic processes such as genetic drift, gene flow, selection, and mating systems (Young and Boyle, 2000). According to Costa et al. (2011), knowing the genetic variation of native species enables the

Genetics and Molecular Research 15 (4): gmr15048630 
development of strategies that allow the domestication and incorporation of these species in regional productive systems, as well as minimizing the environmental impact and establishing effective conservation plans.

Molecular markers are used in genetic assays because of the relative ease of amplifying particular genome regions in order to characterize the genetic diversity and genetic structures of different populations (Sena et al., 2007). Assessing genetic variability is fundamentally important, particularly for understudied native species the diversity of which is not fully known (Costa et al., 2011).

Therefore, the aim of the current study was to characterize the genetic diversity of $T$. speciosum in three urban forest fragments in the municipality of Alta Floresta, Mato Grosso State, Brazil using microsatellite markers, in order to increase our knowledge of the population dynamics of this species and help develop programs for its conservation and exploitation.

\section{MATERIAL AND METHODS}

\section{Study area and sampling}

The study was conducted in three municipality parks in Alta Floresta, Mato Grosso State, Brazil: C/E, with an area of 9.19 ha; J, with 7.38 ha; and the Zoo Botanical, with 17.6 ha (Figure 1).
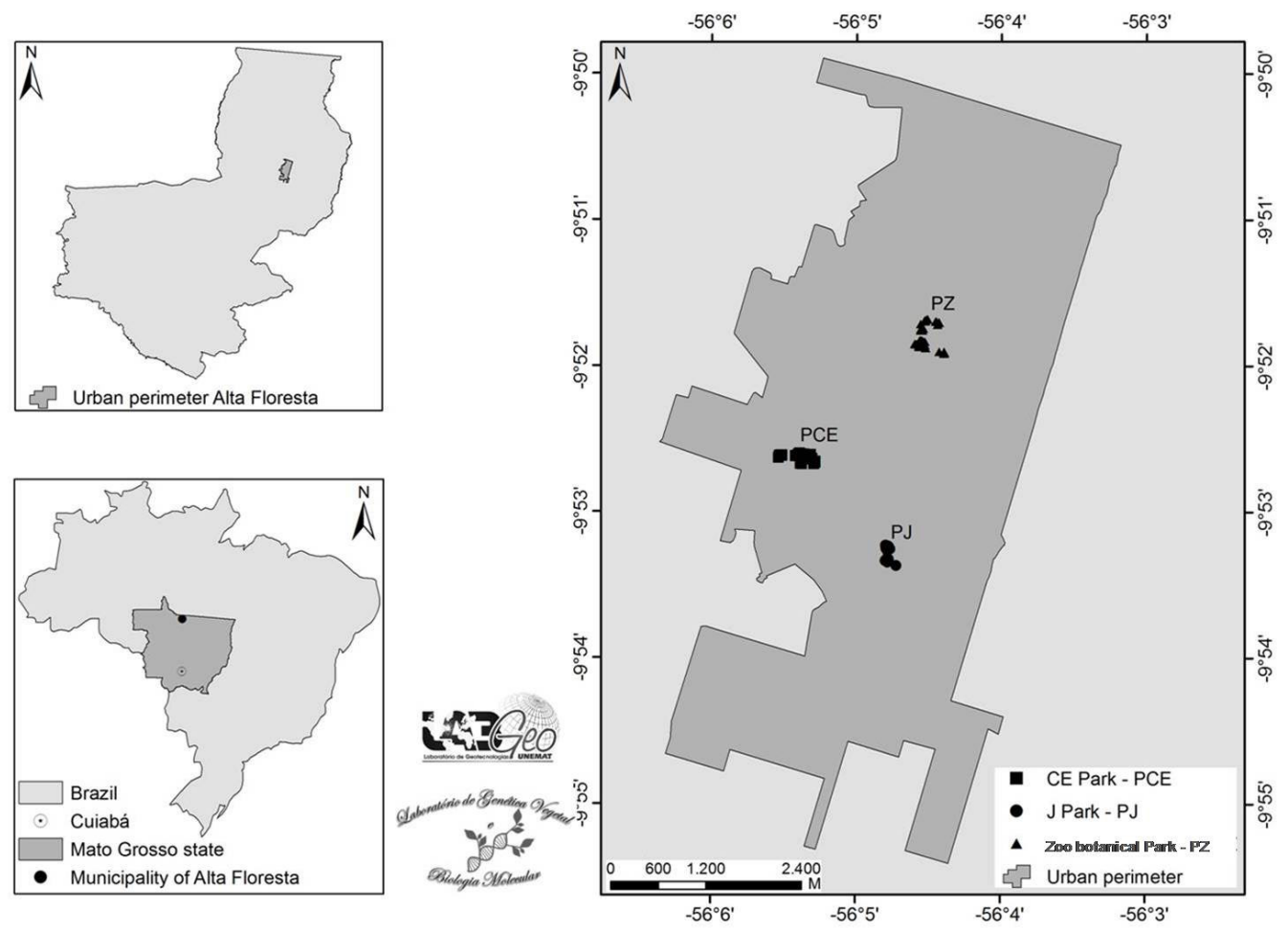

Figure 1. Location of Alta Floresta, Mato Grosso, Brazil and the three urban fragments under study.

Genetics and Molecular Research 15 (4): gmr15048630 
To characterize genetic diversity, $75 T$. speciosum individuals were identified, sampled, and georeferenced in the urban parks ( 25 in each park). Leaf tissue samples were collected for DNA extraction from all of the trees found within the study parks. The samples were stored with silica gel in the field, and subsequently at $-20^{\circ} \mathrm{C}$ in the Genetics Laboratory of the University of Mato Grosso.

\section{DNA extraction}

Total genomic DNA was extracted using the cetyltrimethylammonium bromide method as described by Doyle and Doyle (1990). DNA was applied to an agarose gel (1\% $\mathrm{w} / \mathrm{v}$ ) and stained with ethidium bromide for quantification. Bands were compared with a standard DNA (lambda phage) of known concentration. The gels were then examined using an ultraviolet transilluminator (UVB LTB-21x26) and photographed.

\section{Polymerase chain reaction (PCR) amplification}

Twenty-three microsatellite loci (simple sequence repeats) that were characterized by Lanaud et al. (1999) were tested in an initial PCR amplification using one T. speciosum individual. Of the 23 loci tested, 9 were selected for genetic variability analysis. The amplification protocol followed that described by Lanaud et al. (1999), with some modifications: one initial cycle at $94^{\circ} \mathrm{C}$ for $4 \mathrm{~min}$, followed by 32 cycles at $94^{\circ} \mathrm{C}$ for $30 \mathrm{~s}, 46^{\circ}$ or $51^{\circ} \mathrm{C}$ (depending on the primer used) for $1 \mathrm{~min}, 72^{\circ} \mathrm{C}$ for $1 \mathrm{~min}$, and a final cycle at $72^{\circ} \mathrm{C}$ for $5 \mathrm{~min}$. The amplification products were separated by electrophoresis on a $4 \%(\mathrm{w} / \mathrm{v})$ agarose gel in $1 \mathrm{X}$ TBE running buffer at a constant $85 \mathrm{~V}$ for approximately $5 \mathrm{~h}$. The gel was stained with $0.2 \mathrm{mg} / \mathrm{mL}$ ethidium bromide and subsequently photographed under ultraviolet light using the transilluminator.

\section{Data analysis}

The amplification products were analyzed using the GelQuant Pro program (http:// www.dnr-is.com/Product.asp?Par=3.19\&id=81), in order to develop a matrix based on the fragment sizes of the bands. Principal coordinate analysis (PCA) and analysis of molecular variance (AMOVA) were performed using the GenAlEx 6.5 program (Peakall and Smouse, 2006). We used the PowerMarker program (Liu and Muse, 2005) to assess allelic frequency, genetic diversity, the observed and expected heterozygosity, and the polymorphism information content (PIC). Nei et al.'s (1983) matrix of genetic distance between T. speciosum trees was estimated using the same program. This matrix was imported by MEGA 3.1 (Kumar et al., 2004) to construct a dendrogram of mean distance using the unweighted pair group method with arithmetic mean (UPGMA). The Structure program (Pritchard et al., 2000), which is based on Bayesian statistics, was used to indicate the number of genetic groups $(\mathrm{K})$. We conducted 10 runs for each K value, with 200,000 burn-ins and 500,000 Markov chain Monte

Carlo simulations. To determine the most probable value of $\mathrm{K}$, we used the criteria proposed by Pritchard and Wen (2004) and Evanno et al. (2005).

\section{RESULTS}

The nine primers used in the analysis were polymorphic and amplified 84 alleles,

Genetics and Molecular Research 15 (4): gmr15048630 
with a mean of 9.33 alleles per locus. The highest number of alleles (13) was found at locus mTcCIR19, and the lowest (6) at locus mTcCIR7 (Table 1). The genetic diversity varied between 0.69 (mTcCIR22) and 0.89 (mTcCIR28), with a mean of 0.79 per primer (Table 2).

\begin{tabular}{|c|c|c|c|c|c|}
\hline Locus & $N_{\mathrm{A}}$ & $D_{\mathrm{G}}$ & $H_{\mathrm{E}}$ & $H_{\mathrm{O}}$ & PIC \\
\hline mTcCIR7 & 6 & 0.78 & 0.94 & 0.02 & 0.75 \\
\hline mTcCIR9 & 8 & 0.80 & 0.90 & 0.02 & 0.77 \\
\hline mTcCIR10 & 8 & 0.75 & 0.96 & 0.34 & 0.71 \\
\hline mTcCIR11 & 8 & 0.71 & 0.97 & 0.04 & 0.67 \\
\hline mTcCIR17 & 11 & 0.85 & 0.97 & 0.10 & 0.83 \\
\hline mTcCIR19 & 13 & 0.85 & 1.00 & 0.36 & 0.84 \\
\hline mTcCIR22 & 10 & 0.69 & 0.97 & 1.00 & 0.65 \\
\hline mTcCIR26 & 8 & 0.79 & 1.00 & 0.00 & 0.77 \\
\hline mTcCIR28 & 12 & 0.89 & 1.00 & 0.33 & 0.88 \\
\hline Total & 84 & - & - & - & - \\
\hline Mean & 9.33 & 0.79 & 0.97 & 0.25 & 0.76 \\
\hline
\end{tabular}

Table 2. Genetic diversity of three Theobroma speciosum populations in Alta Floresta, Mato Grosso State, Brazil.

\begin{tabular}{l|c|c|c|c|c}
\hline Population & $D_{\mathrm{G}}$ & $H_{\mathrm{E}}$ & $H_{\mathrm{O}}$ & $\mathrm{F}$ & PIC \\
\hline $\mathrm{C} / \mathrm{E}$ & 0.62 & 0.97 & 0.24 & 0.61 & 0.55 \\
\hline $\mathrm{J}$ & 0.56 & 0.94 & 0.23 & 0.59 & 0.50 \\
\hline Zoo Botanical & 0.54 & 0.99 & 0.26 & 0.52 & 0.47 \\
\hline
\end{tabular}

$D_{\mathrm{G}}$, Nei's genetic diversity; $H_{\mathrm{E}}$, expected heterozygosity; $H_{\mathrm{O}}$, observed heterozygosity; F, fixation index; PIC, polymorphism information content.

All of the loci had high PIC values that varied between 0.65 and 0.88 , with a mean of 0.76 (Table 1), and the loci mTcCIR17, mTcCIR19, and mTcCIR28 had values that were higher than 0.75 .

The mean observed heterozygosity was 0.24 , and it ranged from 0.02 (mTcCIR7) to 1.00 (mTcCIR22), whereas the locus mTcCIR26 did not exhibit any observed heterozygosity $(0.00)$ (Table 1). The mean expected heterozygosity was 0.97 . The observed heterozygosity was lower than the expected heterozygosity, except for locus mTcCIR22 (Table 1). The $T$. speciosum populations had high levels of inbreeding, with a mean of 0.61 for the $\mathrm{C} / \mathrm{E}$ park population, 0.59 for J park, and 0.52 for the Zoo Botanical park (Table 2).

All of the populations exhibited high gene diversity, with the $\mathrm{C} / \mathrm{E}$ park population having the highest (0.62). The expected heterozygosity was 0.97 for the $\mathrm{C} / \mathrm{E}$ park population, 0.94 for the J park population, and 0.99 for the Zoo Botanical park population. The observed heterozygosity was lower than the expected heterozygosity for all of the populations analyzed (Table 2). The PIC was high for all of the fragments ( 0.55 for $\mathrm{C} / \mathrm{E}$ park, 0.50 for J park, and 0.47 for Zoo Botanical park).

The PCA explained $41.11 \%$ of the total variation, with $18.45 \%$ for the first component, $13.96 \%$ for the second, and $8.70 \%$ for the third. We observed the formation of three distinct groups, which were based on genetic similarity and geographical distribution (Figure 2).

Genetics and Molecular Research 15 (4): gmr15048630 


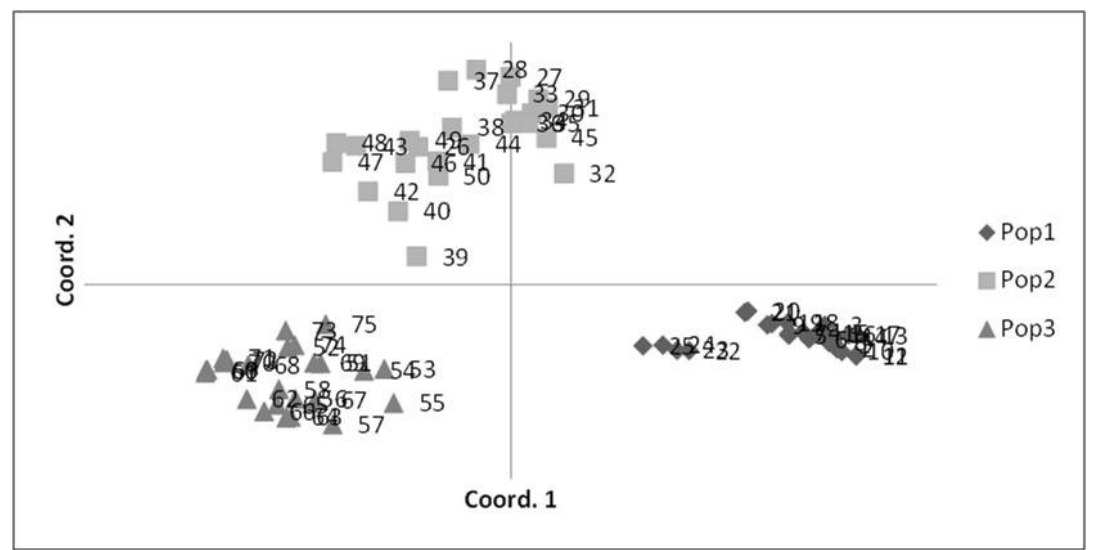

Figure 2. Principal coordinates analysis of 75 Theobroma speciosum individuals from urban forest fragments in Alta Floresta, Mato Grosso State, Brazil.

AMOVA revealed that $64 \%$ of the total variance occurred within populations and $36 \%$ between populations. The dendrogram revealed three principal groups (Figure 3); each group represented a different population, revealing that genetic similarity was high inside each population.

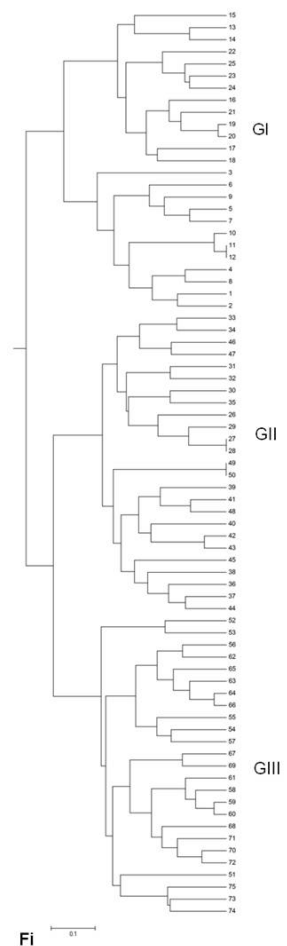

Figure 3. Dendrogram of the genetic similarity among 75 Theobroma speciosum trees. GI, C/E park; GII, J park; GIII, Zoo Botanical park.

Genetics and Molecular Research 15 (4): gmr15048630 
Group I consisted of the C/E park population (genotypes 1-25), which was subdivided into three subgroups: subgroup I, which contained 13 individuals; subgroup II, which included only one individual (genotype 3) and subgroup III, with 11 individuals (Figure 3). In this group, the most similar individuals were 11 and 12, and the most dissimilar was individual 3.

Group II contained the J park population (genotypes 26-50), which was subdivided into two subgroups: subgroup I, which contained the individuals $26,27,28,29,30,31,32$, $33,34,35,46$, and 47 ; and subgroup II, which contained the remainder. In this population, the most similar individuals were 27-28, and 49-50, and the most dissimilar was 45 (Figure 3).

Group III consisted of the Zoo Botanical park population (genotypes 51-75), which contained three subgroups: subgroup I, which included only two individuals (52 and 53); subgroup II, which contained nine genotypes; and subgroup III, which contained the remaining 14 T. speciosum plants. The most similar individuals were $59,60,64$, and 66 , and the most dissimilar was 51 (Figure 3).

The best $\mathrm{K}$ value was found by dividing the samples into three groups $(\mathrm{K}=3)$, which was supported by the clear distributions of individuals in their respective populations (Figure 4).

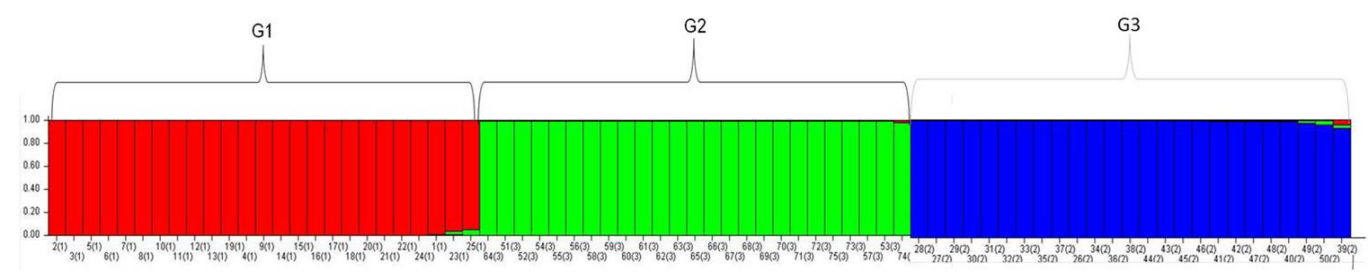

Figure 4. Division of 75 Theobroma speciosum trees into three groups based on molecular data from nine simple sequence repeat loci using the Structure program. Individuals are represented by vertical columns and are shaded according to their group (three genetic groups, $\mathrm{K}=3$ ). G1, C/E park; G2, J park; G3, Zoo Botanical park.

\section{DISCUSSION}

According to Alves et al. (2007), most tropical tree species have a large number of alleles per locus, and, consequently, a high expected heterozygosity. However, Lanaud et al. (1999) and Alves et al. (2013) reported a lower mean number of alleles per locus for T. cacao and T. grandiflorum, respectively, than that found for T. speciosum in the current study, i.e., 4.4 alleles per locus for T. cacao and 3.21 alleles per locus for T. grandiflorum.

The mean PIC values obtained demonstrate the high quality of the markers used. Markers with PIC values higher than 0.5 are considered highly informative, those with values between 0.25 and 0.5 are considered moderately informative, and those with values below 0.25 are minimally informative (Botstein et al., 1980). According to Boza et al. (2013), highly polymorphic markers are useful in identifying genetic diversity.

The observed heterozygosity was lower than the expected heterozygosity in all of the loci analyzed. Our results support those obtained by Zhang et al. (2012), who found higher expected (0.56) than observed (0.38) heterozygosity values in $T$. cacao populations. Alves et al. (2007) obtained a similar result for T. grandiflorum in a study conducted with 21 microsatellite markers, in which the expected $(0.41)$ heterozygosity was higher than the observed (0.35). Motamayor et al. (2002) and Sereno et al. (2006) obtained similar values for T. cacao (expected heterozygosity $=0.54$ and 0.56 , respectively; observed heterozygosity $=$ 0.34 and 0.41 , respectively). 
According to Carvalho et al. (2010), a low heterozygosity rate is associated with reproductive isolation caused by forest fragmentation, because a continuous reduction in population size leads to genetic variability loss through genetic drift.

The loss of genetic diversity in the forest fragments studied here has resulted in T. speciosum exhibiting high inbreeding values. A high inbreeding rate can be caused by the action of monkeys (dispersers), while feeding the fruits of $T$. speciosum, they leave the seeds fall close to the mother tree, where the same germinate and form a new individual. Favoring with this proximity crossings between related individuals and a pattern of aggregate distribution for the species.

Seed dispersal close to the maternal tree favors the formation of a spatial genetic structure (Sobierajski et al., 2006), and increases the possibility of crossings between individuals from the same family, thus generating biparental inbreeding, and, consequently, biparental inbreeding depression. Sebbenn et al. (2011) conducted a study on Copaifera langsdorffii, and found that a small urban fragment may influence seed dispersal distance by limiting the area available for the establishment of seedlings.

AMOVA revealed that much of the genetic variation occurs within populations and not between them. T. speciosum is a perennial species with outcrossing, and consequently accumulate more genetic variability within populations than between them. According to Hamrick et al. (1991), these species exhibit low population differentiation. T. speciosum has a self-incompatible breeding system (Souza and Venturieri, 1998), so it is only effectively pollinated if its pollinators (Drosophila spp) visit other individuals in the population (Silva and Martins, 2004), which increases intrapopulation genetic variability.

The $\mathrm{C} / \mathrm{E}$ park population formed a separate group from the other two populations, probably because it is located in the city center and was the first fragment to be isolated in Alta Floresta county in the 1990s. Because the J park and Zoo Botanical park populations are on the same side of the county and were more recently isolated, we can infer the existence of a corridor that allowed the exchange of genetic material. The most dissimilar individuals in the three populations have the potential to select as stock plants in the formation of germplasm banks, because they were the most genetically distant individuals within the populations. There were similarities between the groupings generated by the Structure program and the dendrogram produced by UPGMA; however, the two methods did not provide the same results, possibly because clusters produced by the Structure program tend to generate greater subgroup differentiation (Romão et al., 2011).

The high genetic diversity detected in the three park populations highlights the importance of maintaining and protecting this species by in situ conservation, as well as the importance of collecting germplasm for ex situ conservation. Because these are fragmented populations wherein the predatory exploitation of fruits prevents their dispersal, and, consequently, natural seedling establishment, the loss of genetic diversity and the genetic erosion of this species may occur in the next few generations.

To conclude, the genotypes of each population were grouped within their population of origin, and exhibited a geographical structure. Genetic diversity was higher at the intrapopulation level than at the interpopulation level. Genotype number 3 from C/E park, number 45 from J park, and number 51 from Zoo Botanical park could be used as stock plants in breeding programs, because they were the most dissimilar within the populations studied. This study provides important information for the adoption of strategies to conserve, characterize, and study T. speciosum in urban forest fragments, by generating indicators that can be used to establish and manage genetic reserves in situ.

Genetics and Molecular Research 15 (4): gmr15048630 


\section{Conflicts of interest}

The authors declare no conflict of interest.

\section{ACKNOWLEDGMENTS}

Research supported by Fundação de Amparo à Pesquisa do Estado de Mato Grosso (FAPEMAT) (Project: Diversidade, Conservação e Uso de Recursos Genéticos de Quatro Espécies Amazônicas de Theobroma com Potencial Econômico para a Região). CAPES/ FAPEMAT scholarships were granted to the first author.

\section{REFERENCES}

Alves RM, Sebbenn AM, Artero AS, Clement C, et al. (2007). High levels of genetic divergence and inbreeding in populations of cupuaçu (Theobroma grandiflorum). Tree Genet. Genomes 3: 289-298. http://dx.doi.org/10.1007/ s11295-006-0066-9

Alves RM, Silva CRS, Silva MSC, Silva DCS, et al. (2013). Diversidade genética em coleções amazônicas de germoplasma de cupuaçuzeiro. Rev. Bras. Frutic. 35: 818-828. http://dx.doi.org/10.1590/S0100-29452013000300019

Botstein D, White RL, Skolnick M and Davis RW (1980). Construction of a genetic linkage map in man using restriction fragment length polymorphisms. Am. J. Hum. Genet. 32: 314-331.

Boza EJ, Irish BM, Meerow AW, Tondo CL, et al. (2013). Genetic diversity, conservation, and utilization of Theobroma cacao L.: genetic resources in the Dominican Republic. Genet. Resour. Crop Evol. 60: 605-619. http://dx.doi. org/10.1007/s10722-012-9860-4

Carvalho ACM, Freitas MLM, Moraes SMB, Moraes MLT, et al. (2010). Diversidade genética, endogamia e fluxo gênico em pequena população fragmentada de Copaifera langsdorffii. Rev. Bras. Bot. Braz. J. Bot. 33: 599-606.

Costa TS, Silva AVC, Ledó AS and de Silva JF, Jr. (2011). Diversidade genética de acessos do banco de germoplasma de mangaba em Sergipe. Pesq. Agropec. Bras. 46: 499-508. http://dx.doi.org/10.1590/S0100-204X2011000500007

Cuatrecasas J (1964). Cacao and its allies: a taxonomic revision of the genus Theobroma. Contribution from the United States National Herbarium, Washington 35: 379-614.

Doyle JJ and Doyle JL (1990). Isolation of plant DNA from fresh tissue. Focus 12: 13-15.

Evanno G, Regnaut S and Goudet J (2005). Detecting the number of clusters of individuals using the software STRUCTURE: a simulation study. Mol. Ecol. 14: 2611-2620. http://dx.doi.org/10.1111/j.1365-294X.2005.02553.x

Ferrão JEM (2001). Fruticultura tropical: espécies com frutos comestíveis. 1st edn. Instituto de Investigação Científica Tropical, Lisboa.

Hamrick JL, Godt MJW, Murawski DA and Loveless MD (1991). Correlations between species traits and allozyme diversity: implications for conservation biology. In: Genetic and conservation of rare plants (Falk DA and Holsinger KE, eds.). Oxford University Press, Oxford.

Kumar S, Tamura K and Nei M (2004). MEGA3: Integrated software for Molecular Evolutionary Genetics Analysis and sequence alignment. Brief. Bioinform. 5: 150-163. http://dx.doi.org/10.1093/bib/5.2.150

Lanaud C, Risterucci AM, Pieretti I, Falque M, et al. (1999). Isolation and characterization of microsatellites in Theobroma cacao L. Mol. Ecol. 8: 2141-2143. http://dx.doi.org/10.1046/j.1365-294x.1999.00802.x

Liu K and Muse SV (2005). PowerMarker: an integrated analysis environment for genetic marker analysis. Bioinformatics 21: 2128-2129. http://dx.doi.org/10.1093/bioinformatics/bti282

Motamayor JC, Risterucci AM, Lopez PA, Ortiz CF, et al. (2002). Cacao domestication I: the origin of the cacao cultivated by the Mayas. Heredity 89: 380-386. http://dx.doi.org/10.1038/sj.hdy.6800156

Nei M, Tajima F and Tateno Y (1983). Accuracy of estimated phylogenetic trees from molecular data. II. Gene frequency data. J. Mol. Evol. 19: 153-170. http://dx.doi.org/10.1007/BF02300753

Neto GG and Silva FHB (2011). Plantas da Amazônia Mato-Grossense: o cacaú- Theobroma speciosum Willd. ex Spreng. (Malvaceae). Flovet 3: 200-209.

Peakall R and Smouse PE (2006). GenAlEx 6: Genetic analysis in Excel. Population genetic software for teaching and research. Mol. Ecol. 6: 288-295. http://dx.doi.org/10.1111/j.1471-8286.2005.01155.x

Pritchard JK and Wen W (2004). Documentation for Structure software: Version 2.1. Available at [http://pritch.bsd. uchicago.edu]. Accessed August 20, 2015.

Genetics and Molecular Research 15 (4): gmr15048630 
Pritchard JK, Stephens M and Donnelly P (2000). Inference of population structure using multilocus genotype data. Genetics 155: 945-959.

Romão LRC, Perseguini JMKC and Rubiano LB (2011). Divergência genética de Seringueira Baseado em Marcadores EST-SSRs. 5th Congresso Interinstitucional de Iniciação Científica-CIIC 20119 a 11 de agosto de 2011. Campinas.

Sebbenn AM, Carvalho ACM, Freitas MLM, Moraes SM, et al. (2011). Low levels of realized seed and pollen gene flow and strong spatial genetic structure in a small, isolated and fragmented population of the tropical tree Copaifera langsdorffi Desf. Heredity (Edinb) 106: 134-145. http://dx.doi.org/10.1038/hdy.2010.33

Sena MC, Oliveira MCS, Reginato LCA, Roese AD, et al. (2007). Fundamentos teórico-práticos e protocolos de extração e de amplificação de DNA por meio da técnica de reação em cadeia da polimerase. Embrapa Pecuária Sudeste, São Carlos.

Sereno ML, Albuquerque PSB and Vencovsky R (2006). Genetic diversity and natural population structure of cacao (Theobroma cacao L.) from the Brazilian Amazon evaluated by microsatellite markers. Conserv. Genet. 6: 13-24. http://dx.doi.org/10.1007/s10592-005-7568-0

Silva AR and Martins MB (2004). A new anthophilic species of Drosophila Fallén belonging to the bromeliae group of species (Diptera, Drosophilidae). Rev. Bras. Zool. 21:435-437. http://dx.doi.org/10.1590/S0101-81752004000300003

Simão S (1998). Tratado de fruticultura. FEALQ, Piracicaba.

Sobierajski RR, Kageyama PY and Sebbenn AM (2006). Sistema de reprodução em nove populações de Mimosa scabrella Bentham (Leguminosaceae). Sci. Forum 71: 37-49.

Souza MS and Venturieri GA (1998). Floral phenology and breeding system of cacauhy (Theobroma speciosum Willd enow-Sterculiaceae). Projeto: Biologia aplicada a domesticação de fruteiras amazônicas do gênero Theobroma. In: Primeiro relatório, Belém.

Souza MS and Venturieri GA (2009). Fenologia Floral e Sistema de Cruzamento do Cacauí (Theobroma speciosum). Available at [http//www.ccb.usfc.br/ giorgini/resumcong.htm].

Young A and Boyle T (2000). Forest fragmentation. In: Forest conservation genetics. Principles and practice (Young A, Boshier D and Boyle T, eds.). CSIRO, Collingwood and CABI, Oxford, 123-134.

Zhang D, Martínez WJ and Johnson ES (2012). Genetic diversity and spatial structure in a new distinct Theobroma cacao L. population in Bolivia. Genet. Resour. Crop Evol. 59: 239-252. http://dx.doi.org/10.1007/s10722-011-9680-y

Genetics and Molecular Research 15 (4): gmr15048630 